\title{
Africans in the Diaspora-The Hidden Force: Economics, Investment, Skilled Workforce and Public Health
}

\author{
Jennyfer Ambe ${ }^{1,2}$, Marion Koso-Thomas ${ }^{3}$, Samuel Adewusi ${ }^{4}$ and Muhammed Afolabi ${ }^{5}$ \\ ${ }^{1}$ Global Emerging Pathogens Treatment Initiative, Mainland Hospital, Yaba, Lagos, Nigeria \\ ${ }^{2}$ Capella University, Department of Public Health, School of Nursing and Health Sciences, \\ Minneapolis, Minnesota, USAjennyferambe@gmail.com \\ ${ }^{3}$ Global Health Researcher, Silver Spring, Maryland mkosot69@gmail.com \\ 4Lawyers Office of Samuel G. Adewusiadewusilaw.sa@gmail.com \\ ${ }^{5}$ Department of Clinical Research, London School of Hygiene \& Tropical Medicine, \\ UKafolabim@gmail.com
}

\begin{abstract}
The Ebola epidemic outbreak in West Africa (2013-2016) left few Africans indifferent. A significant group that contributed appreciably towards the containment of the epidemic was that of Diaporan Africans. In this chapter we highlight the contribution of Africans living outside their homeland to the continent, especially during the West African Ebola epidemic outbreak. Their contributions complemented in many ways the efforts on the ground. The chapter includes the personal narratives of two diasporans: that of Dr. Marion Koso-Thomas, an African Diasporan in the United States and Dr Muhammed Afolabi, an African Diasporan in Africa.
\end{abstract}

Keywords: Africans, Diaspora, dispersal, brain drain, brain gain, social media

\subsection{Introduction}

Diaspora is an ancient Greek term for "dispersion or scattering." The term was used in the modern era, the late 19th century, for the Jewish dispersal from Israel. According to the standard definition of Diaspora, it is the "movement, migration and or scattering of a people from their 
established or ancestral homeland. (Merriam-Webster, n.d.). Many scholars agree that the scattering or dispersal of people from Africa was responsible for populating the globe. The advent of ancient and modern warfare, coupled with ecological and man-made disasters have contributed to dispersal, emigration, immigration and the continuing change of demographics in the world. The African Union (AU) defines the African Diaspora as:

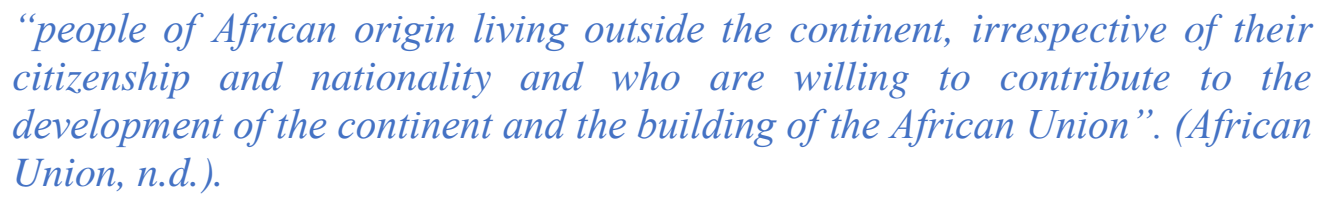

The African Diaspora is referred to as the "sixth region" of Africa. The population of Africans in Diaspora are as follows: Latin America, 112.65 million; The Caribbean, 13.56 million; Europe has 3.51 million; and North America 39.16 million. (World Bank, 2011). As the term is defined, most people do not choose to leave their homeland out of a sense of adventure, but due to lifepreserving and or life-enhancing necessities. For example, Irish immigrants escaped the potato famine from Ireland, and became part of the Irish Diaspora in America. This occurred again as recently as 1973, when Ireland joined the European Union and lost many young skilled workers who migrated in search of work. (Arnold, 2011). Similarly, convicts from London, to include those from the middle class, were sent to Australia in the 1800's. After the convict period, it is unlikely that many voluntarily emigrated to Australia from the slums of London. (Jupp, 2004). Furthermore, the debates surrounding the definition of the word diaspora stems from the fact that this experience is rooted in the experience and consciousness of people who emigrate to new lands. According to Sandra Kim, it is a more phenomenological way of defining the word that gives a better understanding to the term, as this term really encompasses an experience lived by Diasporans. (Kim, 2007).

Diasporans typically engage their homelands through humanitarian relief, financial capital, investment capital and intellectual capital. Contrary to the Brain Drain theory, now with advances of smart phones and the internet, Brain Gain or Brain Circulation are the new terms used, as Africans in diaspora provide intellectual capital which return time and time again to assist whether temporarily, permanently and/or through virtual assistance via social media and cyberspace, enriching home countries. (Chikezie, 2015). Most diasporans will, out of a sense of what is right, obligation and altruism, reach out to help their homeland. Some will invariably forget the homeland and totally assimilate into the new destination culture and society after a period of acculturation. Acculturation has evolved and is now seen as a multidimensional concept which espouses both cultures; that of the home country as well as that of the host country. 
(Ndika, 2013). The choice made by the each individual diasporan depends on the circumstances that led to emigration, and whether or not the homeland contributed to the scattering of said diasporans.

\subsection{Obligation: The Role of Diasporans to the Ancestral Homeland}

It can be argued that diasporans owe no obligation to the ancestral homeland, especially, after the trauma of leaving. If the homeland is viewed as contributorily negligent or culpable in the actions or omissions that led to the dispersal. Based upon anecdotal and factual evidence, we can simply use the Jewish example as a model of the types of obligation that Diaspora owe to the homeland. Notwithstanding, the ambiguities related to the sense of obligations, many diasporans participate and contribute; much like the Jewish Diaspora, who set a shining example and defined the diaspora obligations to the ancestral homeland in the 20th century. The list of obligations is not endless, encompassing financial remittances, the transfer of knowledge and technology, direct foreign investments, donations of medical equipment, non-perishable produce, clothing and kind, and the defending of interests of the homeland in adopted countries. Based on the altruistic nature of each diasporan, she/he chooses the level of obligations, if any at all, and whether to commit resources and time to assist the ancestral homeland. For Africans, there is an outpouring of support through professional and regional associations to the motherland.

The Internet and Social Media. The internet has changed the way people communicate and the speed at which communication is sent and received. Although reference to Social Media is interspersed throughout the chapter, it is befitting to have a section in which some attention is given to the internet as it plays a crucial role in diasporan engagement and second generation diasporans are showing interest in the countries of origin of their parents and grandparents. In the case of the African Diaspora, second generation diasporans are rallying support through social media as human rights advocates and facilitators for change; bringing new ideas and technological know-how. The internet avails diasporans the ability to connect over thousands of miles enabling like-minded diasporans the opportunity to work together to support countries of origin. PayPal and other internet based platforms to send and receive money have made it convenient and cheaper, to send and receive money across continents without exorbitant bank fees. Fund raising platforms such as GoFundMe enables the raising of funds for people all over the world. Social media and groups such as,StopEbolaNow, Ebola Social Media Coalition played a tremendous role in the dissemination of information and rallying of support during the Ebola outbreak. It is important to explicitly consider the leverage of the internet as a communication channel in the event of disasters. Communication can take place before, during and after an 
outbreak or disaster by using social media sites such as Facebook to help with the dissemination of information. Emergency plans and networks can be shared faster via the internet. (Merchant, 2011).

\subsubsection{The Hidden Forces: Economics, Investments and a Skilled Workforce}

In the year 2013, diasporan remittances to their home countries was in excess of 413 billion dollars (USD) (Ratha, 2014). The importance of the diaspora investments cannot be overemphasized. In the United States, data shows that the Chinese and Indian diaspora a lead the pack in active direct foreign investments in their respective ancestral homelands. Both the Chinese and Indian diaspora are followed closely by the Jewish diaspora, and to some extent by the Nigerian diaspora. In the area of remittances to sub-Saharan Africa (sSA), the Nigerian diaspora will remit over $\$ 22$ billion in 2017, according to World Bank estimates. (World Bank, 2017). Several trends point to the growing involvement of diasporas in the development of West Africa. First, the financial volume of remittances sent to countries of origin continues to grow. Such growth is especially intense when families encounter emergency situations, such as in Sierra Leone, where remittances increased by over 50\% between 2013 and 2014 with the Ebola virus disease outbreak. Secondly usage of these resources are spreading the money beyond the migrant family nucleus - for example it is often devoted to building houses - producing spill over effects on trade and related industries. (African Development Bank, 2015).

Due to improved economic activities in certain countries with high incomes and part of the Organisation for Economic Co-operation and Development (OECD); there were higher remittances in 2017. It is estimated that in 2017, formal remittance to sub-Saharan Africa is projected to increase to about $\$ 38$ billion from $\$ 34$ billion in 2016 . This shows an increase of $10 \%$. (World Bank Group, 2017).

There have been many factual stories of individual diaspora investing successfully in Africa. But in most cases, those investments are not large enough to fill the void of significant unemployment. Currently, except for Ghana most of the sSA countries do not have coherent or targeted policies to attract Diaspora investments. In most of the investments forums held in the Western capitals by the SSA governments, the Diaspora is conspicuously absent.

Diaspora Bonds. These bonds are a debt instrument which can be issued by a private organization or a country to raise funds for specific purposes from its diaspora. Israel and India have large diaspora communities and both countries have harvested funds to fill gaps in the country's available resources using this flexible instrument. Since 1951, Israel has issued diaspora bonds for a menu of different needs, every year. India has used this method three times for raise 
funding, when they have had some difficulty in getting through to international capital markets. The combined amount raised by both countries is 44 billion dollars. These bonds offer effective risk management which make them attractive to Diasporans coupled with the sense of obligation or bias towards their home countries. (Ketkar, 2011).

\subsubsection{Consequences of high skill emigration (brain drain) leaving fragile systems}

High skill emigration or brain drain that disperse or migrate from developing countries have serious financial consequences. In the modern age, knowledge and skills are capital. When highly skilled professionals emigrate from developing countries, the immigrants take away valuable capital that are not easily replaceable. To make matters worse, developing countries expend large sums of money to educate and train professionals who in turn leave for one reason or another. The dispersed professionals leave a vacuum of lost tax revenues and spending that are necessary to build strong economies.

Certain African countries have Diaspora affairs and commissions which give attention to bilateral relations and the development of policies for the diasporans which invite them to participate through trade, tourism, image building, humanitarian work, as examples. Many of the governments have recognized brain drain and understand that it is difficult to stop people from leaving. They have come to a consensus that the countries their nationals are emigrating to and the countries of origin need to have a way to capitalize and benefit from the Diasporans. It has been shown that there are documented instances of migration contributing to provide a better outcome for the African country through the additional financial income, resulting economic development and the transfer of technology which reduces unemployment and poverty when correct policies are in place. (Ethiopian Diaspora Policy, 2013).

\subsection{Diasporans and Altruism}

In the area of humanitarian work, the diaspora from sub-Saharan Africa have worked individually and/ or in groups through hundreds of associations; humanitarian, faith-based, tribal, alumni, home town associations and professional organizations - to strengthen and support each other in their new countries and to mobilize resources for the country they left behind. Many diaspora organizations could be further strengthened to serve as valuable intermediaries between traditional development actors, the homeland government, and the broader diaspora, playing a significant development role. Annually, these non-profit as well as professional organizations organize medical missions, training seminars and medical mobile clinics to their countries of origin. 
The Afro-European Medical and Research Network (AEMRN) is an example of efforts by diaspora to enhance skilled labour and invest in brain gain. AEMRN serves as a platform wherein active professionals from such disciplines as education, medicine, engineering, nursing, faith-based can interact at various levels of self-initiated conferences, seminars, workshops, exchange programmes and voluntary work camps in countries with a need. Bern, Switzerland is the European headquarters and Liberia is the Africa Regional headquarters. Projects in health, food security etc. have been initiated in various resource-limited countries especially sub-Saharan Africa. The members of AEMRN are aware of the fact that there are people with trade and professions living under diverse conditions in different parts of the world who, due to one reason or another, are unable to put into useful purpose both for themselves and their communities. AEMRN members identify, reach out, encourage and empower people to take part in continuous professional development programmes so that the stimulus of their learnt trade can be rekindled, improved and once again enable them to contribute to the development of their community and the world at large. (AEMRN, n.d.)

An example of a large diaspora group are Ethiopians who have been migrating for many years. According to Chacko and Gebre, in the 1970's and 1980's, well-educated Ethiopians initially emigrated to Australia, Europe and North America. This was then followed by a labour migration of Ethiopians with a lower socio-economic status to Middle Eastern countries. (Chacko, 2009). In 2013, the Ethiopian government estimated approximately 2 million Ethiopian Diaspora were in other countries in Africa, Australia, Europe, Middle East and North America. The Ethiopian government acknowledges that the Diasporans in Europe and North America have more opportunities for better education and a higher income. They remit money to their families in Ethiopia and invest in different segments of the economy, support Ethiopia with knowledge and lobby for their homeland. (Ethiopian Diaspora, 2013).

\subsubsection{Public Health and Fragile Health Systems}

Given the fragile healthcare systems across sub-Saharan Africa and the dearth of health care professions in certain regions, many Diasporans have formed groups that lobby for and support programs on the continent of Africa. Most African governments have offices for Diaspora and many are actively engaged in activities across the globe. These are activities and the office of the diaspora is usually housed within the Ministry of External Affairs. Often Public Health activities are coordinated through the Ministries of Health and the Ministries of External Affairs. 


\subsubsection{Tapping the diaspora during difficult times: the Ebola outbreak}

When there are ecological disasters, the diaspora are galvanized into action to assist and help the ancestral homeland. When the Ebola outbreak took the countryside of Guinea by surprise, in December 2013, the world was extremely slow to respond despite best efforts from Médecins Sans Frontières (MSF) to draw the world's attention to the crisis and cry for mobilization. Through all of this, upon reflection, it is crucial to note the role that Africans in diaspora played during the outbreak that impacted the ultimate responses in the affected countries of Sierra Leone, Liberia and Guinea-Conakry. An emerging awareness of how diasporans participate in the development of their countries of origin is increasing, especially in humanitarian, education and the public health spheres.

Impact and Involvement of Diaspora Engagement. Although there are no definitive figures, many diaspora medical professionals from sSA volunteered their services and skills during the Ebola outbreak in West Africa. According to the envoy from Sierra Leone, to the United Kingdom, health care professionals in the Diaspora went home since the outbreak began to assist with the situation on hand and help to fight the epidemic. Many individuals walked, cycled, baked and sold cookies and cupcakes, to raise funds to curb the Ebola outbreak. Others donated large sums of money, purchased supplies and equipment, sent clothing and shoes and other personal items through religious organizations and non-profits to the affected countries. On September 30th, 2014 , in the state of New Jersey, United States of America, a 75-mile bike ride to raise $\$ 3,300$ took place to support Médecins Sans Frontières fight against EVD. Others formed non-profit organizations, like the five young individuals of Sierra Leonean descent; who formed EndEbolaNow.com which is a website that was instrumental in raising awareness through education and funding for the fight against Ebola Virus Disease. They teamed with Emergency USA and formed the hashtag \#ShakeEbolaOff which was a dance campaign which took social media by storm. (Walton, 2014). The Kono District Development Association in the United Kingdom put together personal protective equipment (PPE), chlorine powder and hand sanitizers and shipped the supplies to the Kono District, Sierra Leone. Supplies were distributed to 14 chiefdoms and communications on how to prevent the spread of the disease were successfully carried out.

Liberia. There is an estimated 72,000 Liberians living in the United States.In July 2014, the Liberian Ambassador to the United States of America, responded to countless calls from Liberians in the United States asking for ways to assist their brothers and sisters on the ground. The Ambassador, Jeremiah Sulunteh asked diasporans to donate to the Global Ministries who were about to ship a container of medical equipment and supplies early August. He asked for Liberians 
and all well-wishers to assist with donating items. He also stated that the embassy in Washington D.C. would set up a bank account for to fight Ebola Virus Disease, for those who wish to donate money. He assured the diasporans that there will be accountability and transparency to ensure that all funds collected for the outbreak are used specifically for the outbreak. (Butty, 2014).

Liberians in diaspora galvanized through associations and actively used social media. Following the evacuation of non-essential personnel and family members from Liberia, by the State Department, a call came from the Liberian Vice President, Joseph Bokai in which he pleaded with diasporans to call family members in Liberia and advise them to heed and obey the calls put forth by the Liberian government. He appealed to diasporans to educate their relatives and advise them about Ebola Virus Disease amidst skeptical, risky behaviour with many people denying that EVD truly exists, much less the concern of it being a threat in any way. (Butty, 2014).

Guinea (Conakry). The Ebola Virus Disease outbreak of 2014-2016, was the first of its kind in West Africa. The Guinean Community Association of the District of Columbia, Maryland and Virginia, in the United States, actively participated in coordinating efforts to curtail the Ebola Disease outbreak by organizing, coordinating and supporting public health and community engagement work in Guinea. The association was key in lobbying for assistance from the United States for a response to the affected region. Guinean diasporans donated clothing, shoes, water and other items and pooled their resources to ship the merchandise home. Many used huge drums instead of cardboard boxes to ship the merchandise so that the drums could then be used to store clean, chlorinated water.

\subsection{Narratives from the field}

Sierra Leone (a personal narrative). The following contribution is a personal narrative by Dr. Marion Koso-Thomas, a Diasporan in the United States. This narrative serves as an example of the impact and involvement of diaspora engagement during the Ebola Virus Disease outbreak of 2013-2016.

In August 2014, the Sierra Leone Ambassador to the United States invited Dr Koso-Thomas to a town hall meeting in Washington, D.C where he proposed the formation of a Task Force to coordinate efforts of Sierra Leoneans in the metropolitan area. With the plethora of health experts in the region who were making inquiries of how they could contribute to curbing the epidemic, it was clear to him that there was an untapped potential. A physical therapist along with several physicians and nurses were invited to constitute the US-Sierra Leone Healthcare Coalition Taskforce. The group met with a U.S. based organization with collaborative work in 
Sierra Leone, and the State Department and attended briefings on the Hill to serve as a voice for advocacy. Though the Task Force was unable to directly deploy individuals with the relevant expertise, the intent was to provide the Ministry of Health and the government of Sierra Leone with support. The Task Force was able to compile a list of health care workers in the DMV, Delaware and Philadelphia metropolitan areas which quickly grew to over 100 names. The professionals listed had a range of the technical competencies, social, cultural, and language competencies that gave them the added advantage of being able to rapidly deploy, without the need for interpreters/translators and could also be an incredible resource for training their local counterparts. Unfortunately, the Task Force was unable to aid in the formal collective deployment of these volunteers; a challenge in the Ebola epidemic response which played a role in critical delays.

In February 2015, Dr Koso-Thomas, a physician and public health professional whose native country is Sierra Leone, was invited by the Centers for Disease Control (CDC) to be deployed as an Infection Prevention Control (IPC) Specialist and Epidemiologist serving on the Ebola Emergency Response Team. As part of the team, she served on the District Ebola Response Command and Control Center (DERC) in Kambia which was one of the last resistant sites where the epidemic stubbornly persisted. Due to her expertise, she led IPC training for Category 1 and Category 2 staff of the Kambia District General Hospital and Epi investigation of EVD case (in collaboration with the World Health Organization).

\subsection{Africans in Diaspora within Africa}

Many Africans working outside their home countries, yet within Africa, also contributed significantly to bring the outbreak of Ebola to a conclusive end. Following successful control of Ebola in Nigeria, there was a clarion call that the Government of Nigeria should share with other countries how they successfully achieved the control of the outbreak within a relatively short period with countries. The Ministry of Health of Lagos State, led by Honourable Commissioner, Dr Jide Idris, invited volunteer health workers to share their expertise in neighbouring Sierra Leone, Guinea-Conakry and Liberia. This led to the deployment of several epidemiologists, nurses, paediatricians, laboratory scientists and community workers to Ebola-affected countries where they worked assiduously with the organisations and governments of the respective countries to bring the outbreak under control well before the time projected that it would end.

\subsubsection{Post Ebola Outbreak: Another Personal Narrative}

Dr Muhammed Afolabi was working in one of the leading research institutions in The Gambia, West Africa, during the outbreak. Although, there was no outbreak of Ebola in The Gambia, the 
fear that it would enter the country kept everyone on their toes. Dr Afolabi was looking for opportunities to contribute his quota to alleviating the unquantifiable human suffering wrought by the outbreak. The opportunity soon came when the head of his research organisation invited him to his office one afternoon to inform him that the organisation had been selected to be part of a consortium with the responsibilities of testing the safety and efficacy of an Ebola vaccine within six months. That sounded like an unbelievable feat, as it normally takes a minimum period of 10 ten years to test and roll-out a vaccine for any disease. However, due to the deadly nature of Ebola without a known cure or vaccine, the World Health Organization insisted on fast-tracking the development and testing of the vaccine to address the huge challenges posed by the virus.

Dr Afolabi was chosen to coordinate the vaccine testing and evaluation for his organisation. Despite involvement in many other pressing research issues, he tackled the onerous task headlong working round the clock with other colleagues to develop and finalise the clinical trial protocol, study documents as well as ethical and regulatory approval from local, national and international committees. Sensitization efforts in the selected trial communities took place to ensure buy-in and meaningful engagement of the potential study participants and their families. Everything appeared set for the take-off of the Ebola vaccine testing, when the President of the country refused blatantly to give a nod for the trial to proceed. He did not see any reason why the organisation should be using his citizens as guinea-pigs to test Ebola vaccine especially when he thought he had a cure for it. Many advocacy efforts made to assuage his feelings proved abortive.

Towards the Fall of 2016, Dr Afolabi joined a leading academic institution which was testing another Ebola vaccine among adults, adolescents and children in the northern district of Sierra Leone. This afforded him the opportunity to translate the knowledge and skills gained in his previous work place to ensure the research staff were properly trained, and good quality data collected. His greatest hope is that this current effort would lead to the licensure of an Ebola vaccine which can be deployed to stem the tide of Ebola whenever it rears its ugly head again, anywhere in the world.

In conclusion, Africans in diaspora play a critical role despite their physical absence from the continent and/or on the continent but away from their home countries. Many diasporans straddle the continent they live in and their home countries, travelling back to visit with family during important times and during the holiday seasons. They are comprised of people from all walks of life; from blue collar workers to white collar professionals in the fields of entrepreneurship, inventors, science, medicine and healthcare. No matter the diaspora's job in the new or host country, most diasporans have the same goal of sending funds, books, and 
electronics and clothing home to family and providing support for extended family, clans and hometowns. Financial remittances are a major infusion of foreign currency for some African countries. Diasporan investments and foreign exchange funding is critical to the development of economies in Africa due to the sheer magnitude of the influx in currency with a high increase during certain festive seasons. Although there are no conclusive figures, it appears that most diasporans have the interest of their countries of origin at heart, due to emotional attachments and familial obligations. They contribute their knowledge, technical savviness through brain power in addition to financial remittances and lobbying activities. Disaporans feature prominently in the development projects of home countries and assist with the building of businesses through ingenuity and entrepreneurship.

\subsection{References}

- African Union, (n.d.). The Diaspora Division. https://au.int/en/diaspora-division

- Afro-European Research and Medical Research Network. n.d. http://www.aemrnetwork.ch/index.php/en/

- Butty, J. 2014. Liberia diaspora mobilizing for ebola relief. Washington: Federal Information \& News Dispatch, Inc.

- Butty, J. 2014. VP urges diaspora Liberians to help educate relatives about Ebola. Lanham: Federal Information \& News Dispatch, Inc.

- Chacko, E., \& Gebre, P. H. 2013. Leveraging the diaspora for development: Lessons from Ethiopia. Geojournal, 78(3), 495-505. doi:10.1007/s10708-012-9447-9

- Chikezie, C., (2015, June). The Ebola Crisis and Sierra Leone, Humanitarian Practice Network. Retrieved from http://odihpn.org/magazine/the-ebola-crisis-and-the-sierraleone-diaspora/

- Ethiopian Ministry of External Affairs. Diaspora Policy. Retrieved from http://www.ethiopianembassy.org/PDF/diaspora\%20policy.pdf

- Envoys task Africans in diaspora on ebola virus. 2014. AllAfrica.com

- Jupp, J., \& ProQuest Ebooks. (2004). The English in Australia. Cambridge, UK;New York; Cambridge University Press.

- Ketkar, S. L., \& Ratha, D. 2011. VIEWPOINT: Diaspora bonds for funding education. Migration Letters, 8(2), 153-172. Retrieved from http://library.capella.edu/login?url=https://search-proquestcom.library.capella.edu/docview/1268704155?accountid $=27965$

- Kim, S., (2007). Redefining diaspora through a phenomenology of postmemory. Diaspora: A Journal of Transnational Studies, 16(3), 337-352. doi:10.1353/dsp.2007.0015 
- Pai, M. Opinion: How can immigrant scientists give back to their homelands?http://publications.mcgill.ca/medenews/2017/09/29/opinion-how-canimmigrant-scientists-give-back-to-their-homelands/

- Ojo, S., Nwankwo, S., \&Gbadamosi, A. 2013. African diaspora entrepreneurs: Navigating entrepreneurial spaces in 'Home' and 'Host' countries. The International Journal of Entrepreneurship and Innovation, 14(4), 289-299. doi:10.5367/ijei.2013.0126

- Online Etymololgy Dictionary. (n.d.). Retrieved from https://www.etymonline.com/

- Merchant, R. M., Elmer, S., \& Lurie, N. 2011. Integrating social media into emergencypreparedness efforts. The New England Journal of Medicine, 365(4), 289-291. doi:10.1056/NEJMp1103591

- Merriam-Webster. n.d.https://www.merriam-webster.com/dictionary/diaspora

- Migration and Remittances: Fact book 2011 World Bank. (2014). African Diaspora. https://siteresources.worldbank.org/INTDIASPORA/Resources/AFR Diaspora FAQ.pdf

- Ndika, N. (2013). Acculturation. SAGE Open, 3(4) doi:10.1177/2158244013515687

- Walton, A.2014. Grassroots Social Media Campaign Aims To Raise \$1 Million In The Ebola Fight. Forbes. Retrieved from https://www.forbes.com/sites/alicegwalton/2014/10/21/social-media-campaigns-tostop-ebola-gain-strength-celebrity-support/\#1a86eab1fe1e

- World Bank Group. (October, 2017). MIGRATION AND DEVELOPMENT BRIEF 28 Migration and Remittances: Recent Developments and Outlook Special Topic: Return Migration October 2017. https://www.afdb.org/en/blogs/measuring-the-pulse-of-economictransformation-in-west-africa/post/remittances-from-west-africas-diaspora-financialand-social-transfers-for-regional-development-14614/ 